\title{
ANALISIS RISIKO PEMBANGUNAN JALAN TOL PADA TAHAP KONSTRUKSI (STUDI KASUS JALAN TOL PEKANBARU-DUMAI)
}

\author{
Ari Sandhyavitri, Muhammad Zulfiqar \\ Jurusan Teknik Sipil, Fakultas Teknik, Universitas Riau \\ Kampus Bina Widya Jl. HR. Soebreantas KM 12,5 Pekanbaru, Kode Pos 28293 \\ e-mail: arisandhyavitri@gmail.com dan muhammad.zulfiqar.0707120170@gmail.com
}

\begin{abstract}
The existing Pekanbaru-Dumai highway (consist of 2-lane 2-way) is as an important transportation system connecting several cities in the Riau Province. It was forecasted that the highway would be overcapacity by the year 2015. Hence, the toll road was planned to overcome the problem. However, the investment for the construction of the toll road may involves some level of risks and uncertainties, the risk analyses procedure may put into account for managing the risks. The purpose of this study is to identify and analyze the project risks (during project construction phase). This study measured the value of the risk probabilities and risk impacts that may occur during this construction phase. The magnitude of each single risk is analyzed and simulated using @Risk software package. In order to obtain data input, the filed survey was conducted in two main stages e.i.; preliminary survey, and detailed survey. Then analyzed was carried out based on stochastic analyses. The result findings were then compared to the parameters published by the Puslitbang Pd-T-01-2005-B, 2005. It was identified that four major risks were influenced during the project construction phase, as follow; risk of the project finance, risk of the project construction, equipment risk and force majeure. The magnitude of the risks that may occur during project construction was identified as a medium risk category, which needs special intention to be preceded.
\end{abstract}

Keywords: Risk Analysis, Impact, Pekanbaru-Dumai, Toll Road, Probability.

\begin{abstract}
ABSTRAK
Ruas Jalan yng menghubungkan antara Kota Pekanbaru-Dumai (terdiri dari 2-lajur 2-arah) adalah merupakan urat nadi transportasi penting di Provinsi Riau. Diproyeksikan ruas jalan ini akan over kapasitas pada tahun 2015. Oleh karena itu direncanakan akan diabgun jalan tol untuk mengatasi masalah tersebut. Namun, investasi untuk pembangunan jalan tol melibatkan beberapa tingkat risiko dan ketidakpastian, maka analisis dan pengelolaan risiko diperlukan dalam proses pembangunan jalan tol ini. Tujuan dari penelitian ini adalah untuk mengidentifikasi dan menganalisis risiko proyek (selama proyek tahap konstruksi). Studi ini mengukur nilai probabilitas risiko dan dampak risiko yang mungkin terjadi selama tahap konstruksi jalan tol. Besarnya masing-masing risiko dianalisis dan disimulasikan menggunakan perangkat lunak@ Risk. Dalam rangka untuk mendapatkan input data, survei dilaksnakan dalam dua tahap utama; (i) survei awal, dan (ii) survei detil. Kemudian dilakukan analisis risiko berdasarkan stokastik. Hasil analisis kemudian dibandingkan dengan parameter-parameter risiko yang diterbitkan oleh Puslitbang Pd-T-01-2005-B 2005. Diidentifikasi empat risiko utama yang dipengaruhi selama tahap konstruksi proyek, sebagai berikut; (i) risiko pembiayaan proyek, (ii) risiko pembangunan proyek, (iii) risiko peralatan, dan (iv) force majeure. Besarnya risiko yang mungkin terjadi selama proyek konstruksi jalan tol ini diidentifikasi sebagai kategori risiko sedang, yang membutuhkan penanganan khusus.
\end{abstract}

Kata kunci: analisis risiko, dampak, Pekanbaru-Dumai, jalan tol, probabilitas.

Analisis Risiko Pembangunan Jalan Tol Pada Tahap Konstruksi 


\section{PENDAHULUAN}

\section{Latar Belakang}

Berdasarkan konsep Masterplan Percepatan dan Perluasan Pembangunan Ekonomi Indonesia (MP3EI) koridor Sumatera, Kota Pekanbaru dan Kota Dumai merupakan wilayah yang berada dalam cakupan jalur penghubung pusat ekonomi. Oleh karena itu, perlu diadakannya akses yang lebih cepat untuk menghubungkan kedua kota tersebut (MP3EI 2011-2025, 2011).

Kota Dumai terletak disebelah utara Kota Pekanbaru dengan jarak 199,45 km. Ruas jalan Pekanbaru-Dumai saat ini merupakan jalur penting yang termasuk dalam jalur lalu lintas timur pulau Sumatera. Kota Dumai merupakan pelabuhan penting yang menjadi pintu keluar masuk barang untuk dan dari Riau, sedangkan Kota Pekanbaru merupakan titik kumpul bagi kabupaten-kabupaten di Propinsi Riau.

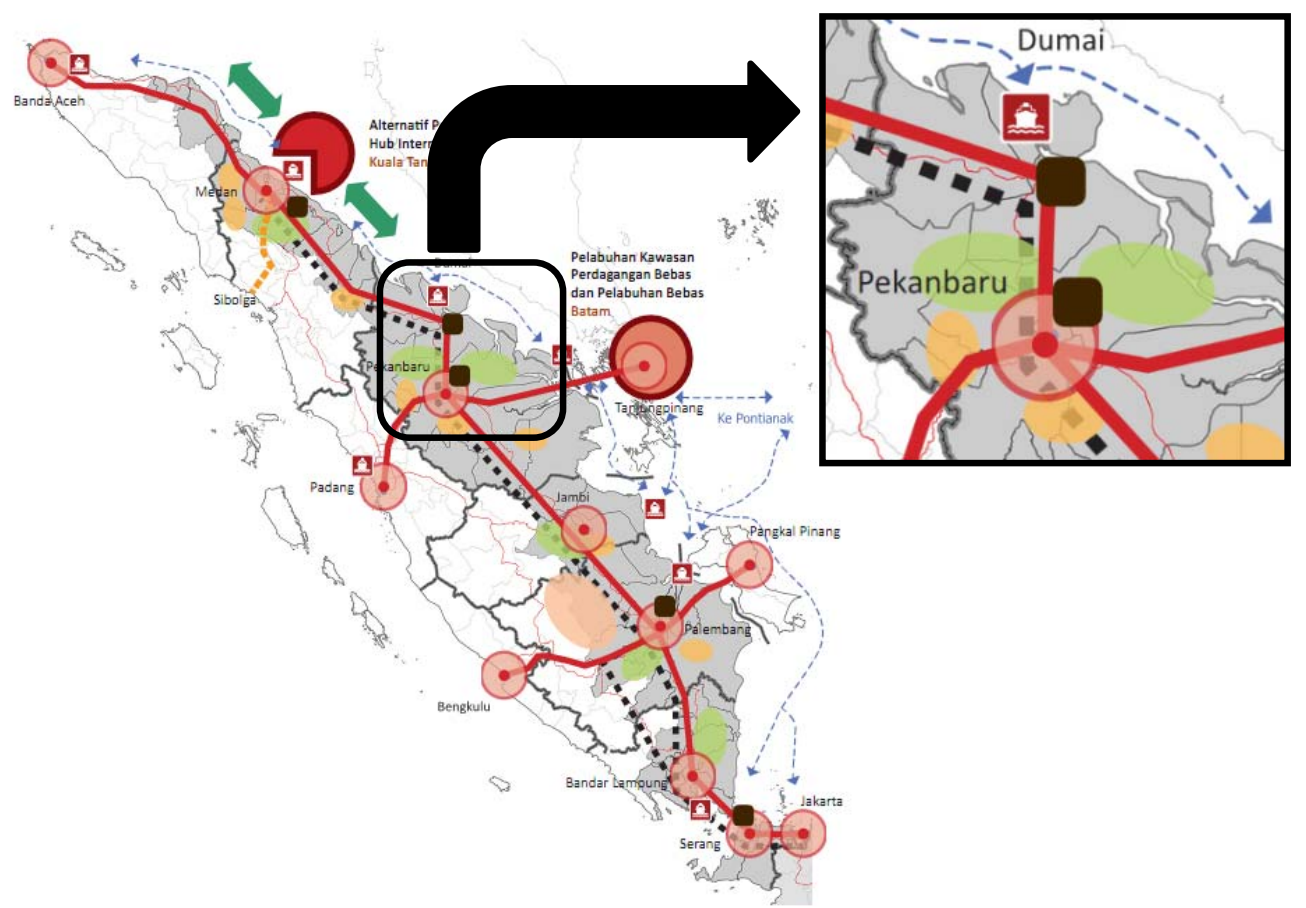

Gambar 1.Overview Koridor Ekonomi Sumatera.

Sumber: MP3EI 2011-2025, 2011 

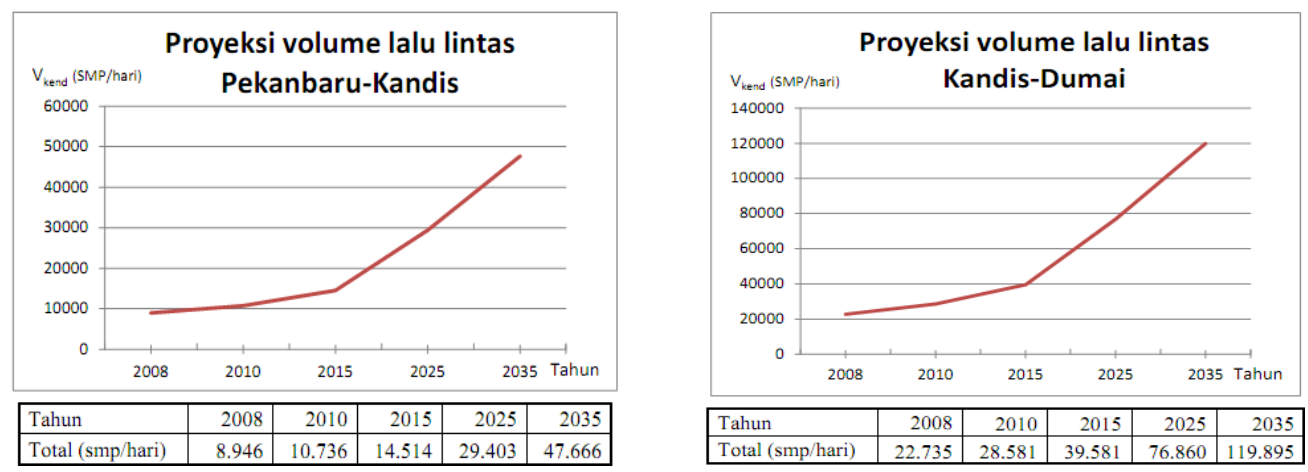

Gambar 2. Grafik Proyeksi Volume Lalu Lintas Pekanbaru-Dumai.

Sumber: Presentasi Tol Pekanbaru-Dumai oleh Gubernur Riau, 2000

Berdasarkan Gambar 2 diatas diproyeksikan pertumbuhan rata-rata volume kendaraaan yang melewati ruas jalan Pekanbaru-Kandis dari tahun 2008-2010 sekitar 20\% sedangkan setelah tahun 2010-2015 volumenya meningkat 35\%, dandiproyeksikan volume kendaraan ruas jalan Pekanbaru-Kandis setelah dibangunnya jalan tol PekanbaruDumai pada tahun 2015 dengan total 14.514 SMP/hari.Sedangkan untuk ruas jalan Kandis-Dumai diproyeksikan pertumbuhan rata-rata volume kendaraaan dari tahun 20082010 meningkat sekitar 25\% dan tahun 2010-2015 volumenya terus meningkat sebesar 38\%, dan diproyeksikan volume kendaraan ruas jalan Kandis-Dumai pada tahun 2015 dengan total 39,581 SMP/hari sedangkan kapasitas jalan Pekanbaru-Dumai 27.936 SMP/hari, maka dilihat kondisi ruas jalan Kandis-Dumai yang 2 lajur dan 2 arah diprediksi ruas ini akan mengalami overcapacity di tahun 2015 (Zulfery, 2004). Untuk mengatasi pertumbuhan lalu lintas dan meningkatan efisiensi jasa distribusi guna menunjang pertumbuhan ekonomi di Provinsi Riau maka direncanakanlah jalan tol Pekanbaru-Dumai. (Presentasi Jalan Tol Pekanbaru-Dumai oleh Gubernur Riau, 2000).

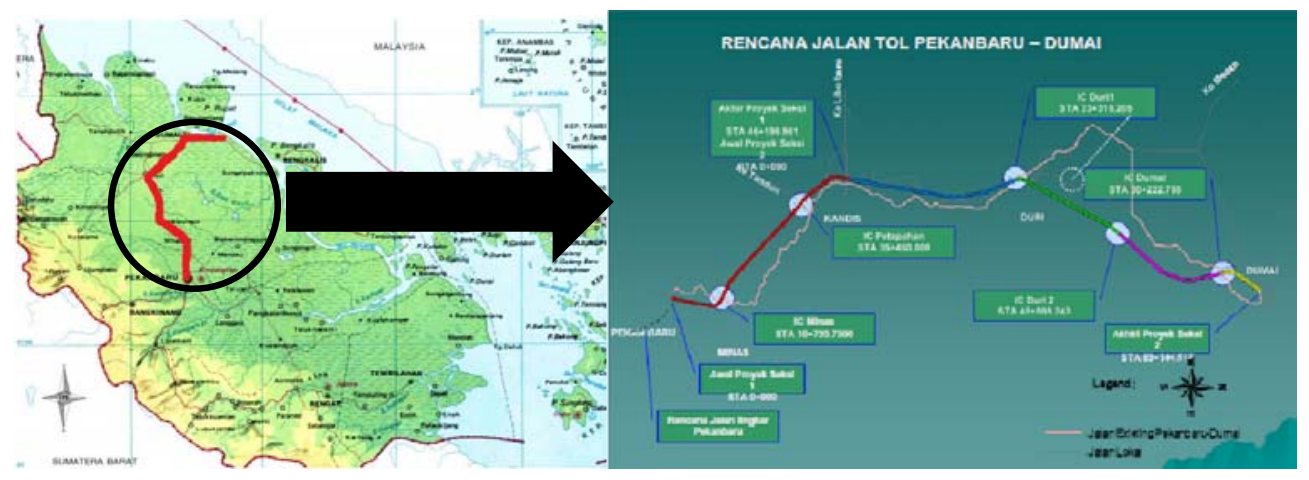

Gambar 3. Peta Lokasi Pengembangan Jalan Tol Pekanbaru-Dumai.

Sumber: Presentasi Tol Pekanbaru-Dumai oleh Gubernur Riau, 2000

Analisis Risiko Pembangunan Jalan Tol Pada Tahap Konstruksi 3

(Studi Kasus Jalan Tol Pekanbaru - Dumai) (Ari Sandhyavitri, Muhammad Zulfiqar) 
Berdasarkan perencanaan jalan tol Pekanbaru-Dumai dibagi dalam 3 seksi utama yaitu: seksi I Pekanbaru-Kandis, seksi II Kandis-Duri, seksi III Duri-Dumai. Sedangkan untuk gerbang tol dibagi dalam 5 interchange (IC) yaitu: IC Minas, IC Petapahan, IC Duri I, IC Duri II, IC Dumai.

Diestimasi investasi pembangunan jalan tol ini (pada tahap konstruksi) adalah Rp. 14,66 triliun. Dengan besarnya nilai investasi yang akan ditanamkan maka perlu dilakukan analisis risiko tahap konstruksi dalam rangka mengidentifikasi risiko yang mungkin terjadi dan memahami probabilitas dan dampak dari cost overruns.

\section{Tujuan Penelitian}

Tujuan dari penelitian ini adalah:

1. Identifikasi faktor-faktor risiko yang mungkin terjadi pada masa konstruksi pada jalan tol Pekanbaru-Dumai. (berdasarkan probabilitas risiko dan nilai dampak risiko dalam parameter yang terukur).

2. Analisis dan simulasi risiko dalam bentuk stokastik.

\section{TINJAUAN TEORI}

\section{Pengertian Risiko dan Analisis Risiko}

Risiko adalah kombinasi probabilitas suatu kejadian dengan konsekuensi atau akibatnya (Siahaan, 2007). Analisis risiko adalah metode untuk mengidentifikasi dan mengukur risiko, pengembangan, seleksi dan program manajemen untuk menghadapi risiko tersebut dalam sebuah cara yang terorganisir.

Hal ini meliputi tiga aspek yaitu: identifikasi risiko, penilaian risiko dan pengelolaan risiko (Albahar, 1990; Flanangan, 1993; Bing; 1990).

\section{Manajemen Risiko}

Manajemen risiko adalah proses sistematik dari perencanaan, identifikasi, analisis, pemberian respon, dan pengawasan dari risiko-risiko proyek. Manajemen risiko melibatkan proses-proses, alat-alat, dan teknik-teknik yang akan membantu manajer memaksimalkan kemungkinan dan konsekuensi dari kejadian-kejadian positif dan meminimalkan kemungkinan dan konsekuensi dari kejadian-kejadian negatif. 


\section{Analisis Tingkat Risiko}

Analisis tingkat risiko didasarkan pada persamaan faktor risiko investasi, dimana besaran-besaran faktor risiko tersebut merupakan gambaran mengenai tingkat risiko investasi yang terjadi. Persamaan faktor risiko didefinisikan sebagai perkalian antara besaran dampak dan probabilitas kejadian risiko, yang dihitung dari persamaan berikut ini, yaitu:

$$
\mathrm{FR}=\mathrm{L}+\mathrm{I}-(\mathrm{L} \times \mathrm{I})
$$

dengan: $\mathrm{FR}=$ Faktor risiko, dengan skala $0-1$

$\mathrm{L} \quad=$ Probabilitas kejadian risiko

$\mathrm{I}=$ = Besaran dampak (impact) risiko dalam bentuk kenaikan biaya

Tabel 1. Kategori Risiko.

\begin{tabular}{|c|c|l|}
\hline Nilai FR & Kategori & \multicolumn{1}{|c|}{ Langkah Penanganan } \\
\hline$>0,7$ & Risiko Tinggi & $\begin{array}{l}\text { Harus dilakukan penurunan risiko ke tingkat } \\
\text { yanglebih rendah }\end{array}$ \\
\hline $0,4-0,7$ & Risiko Sedang & $\begin{array}{l}\text { Langkah perbaikan dibutuhkan dalam jangka } \\
\text { waktu tertentu }\end{array}$ \\
\hline$<0,4$ & Risiko Rendah & Langkah perbaikan bilamana memungkinkan \\
\hline
\end{tabular}

Sumber: Puslitbang Pd-T-01-2005-B, 2005

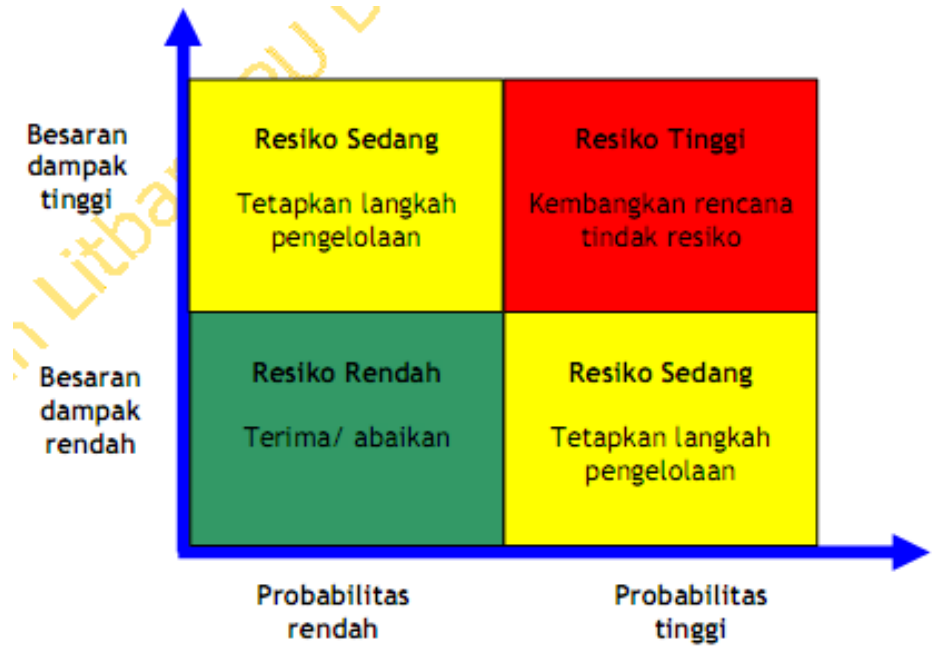

Gambar 4. Matriks Kategori Risiko.

Sumber: Puslitbang Pd-T-01-2005-B, 2005 


\section{HASIL DAN PEMBAHASAN}

\section{Hasil Pra Survei Pendahuluan}

Berdasarkan hasil pra survei pendahuluan dididentifikasi 4 faktor risiko utama yaitu pembiayaan, pembangunan, peralatan, dan force majeur.

Resiko pembiayaan meliputi kontinuitas sumber dana, bunga masa konstruksi, obligasi/bond dan resiko dalam pengembalian pinjaman.

Resiko pembangunan yaitu; ketidak pasatian kondisi lapangan baik kondisi lahan, kondisi tanah dan kondisi cuaca, pasokan material, pencurian, spesifikasi teknis, mismanajemen, mogok kerja, ketidak pastian skedul (jadwal) pelaksanaan, estimasi biaya konstruksi, dan fluktuasi tingkat inflasi, dan ketidak jujuran dalam pelaksanaan proyek.

Resiko peralatan yaitu; ketidak pastian proses impor, dan kinerja alat yang rusak. Resiko force majeur meliputi; bencana alam, nasionalisasi dan revolusi.

\section{Probabilitas Kejadian Risiko}

Adapun hasil pengukuran kemungkinan/probabilitas risiko pada pembangunan jalan tol Pekanbaru-Dumai dapat dilihat pada Gambar 5.

Probabilitas kejadian risiko pada faktor risiko pembiayaan menunjukkan relatif kecil perbedaan antara hasil penelitian ini dengan parameter yang dikeluarkan Pd-T-012005-B dengan selisih sekitar 8\%. Begitu juga dengan resiko pembangunan dan penjadwalan. Sedangkan pada force majeur terdapat selisih sekitar yang relatif besar (34\%). Probalitas terjadinya kejadian yang tidak diinginkan berupa bencana alam (force major) yang mempengaruhi pelaksanan proyek jalan di Propinsi Riau selama ini relatif kecil.

Dengan demikian dapat diketahui bahwa kemungkinan (probabilitas) terjadinya faktor risiko tahap konstruksi pada pembangunan jalan tol Pekanbaru-Dumai pada umumnya realtif lebih kecil bila dibandingkan dengan tipikal kemungkinan (Probabilitas) risiko pembangunan jalan tol di Indonesia yang bersumber dari Puslitbang PU. 


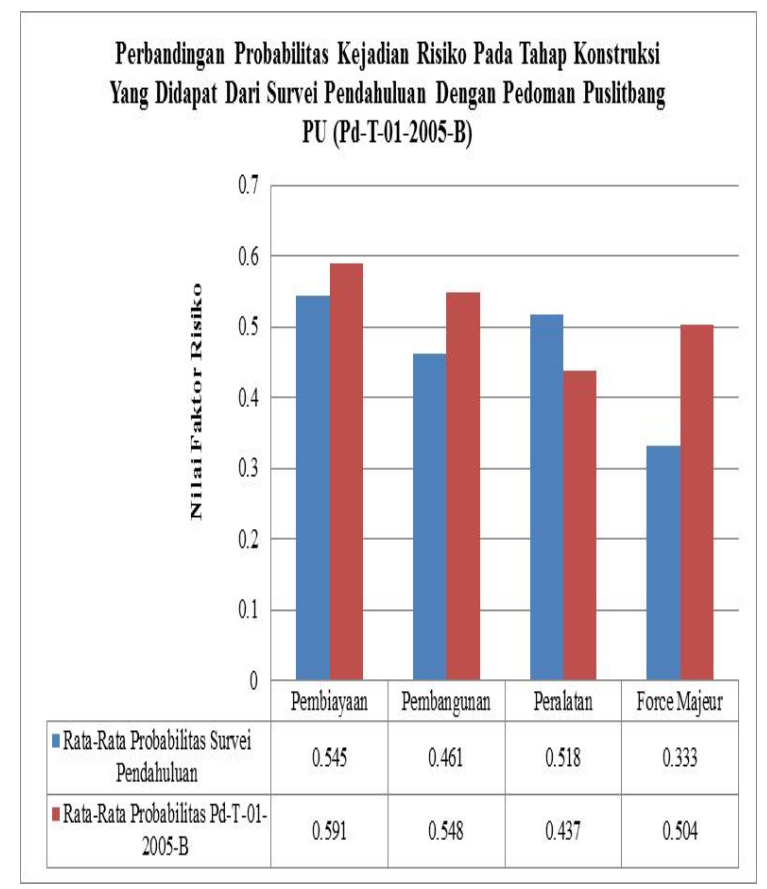

\begin{tabular}{|c|l|c|c|}
\hline \multicolumn{2}{|c|}{ Tahap Konstruksi } & Survei Pendahuluan & Pd-T-01-2005-B \\
\cline { 2 - 4 } \multicolumn{2}{|c|}{} & $\begin{array}{c}\text { Rata-Rata } \\
\text { Probabilitas }\end{array}$ & $\begin{array}{c}\text { Rata-Rata } \\
\text { Probabilitas }\end{array}$ \\
\hline 1. & Pembiayaan & 0,545 & 0,591 \\
\hline & Kontinuitas Sumber Dana & 0,607 & 0,640 \\
\hline & Bunga Masa Konstruksi & 0,500 & 0,627 \\
\hline & Obligasi/Bond & 0,500 & 0,558 \\
\hline & Pengembalian Pinjaman & 0,571 & 0,631 \\
\hline 2. & Pembangunan & 0,461 & 0,548 \\
\hline & Kondisi Lapangan & 0,607 & 0,535 \\
\hline & Kondisi Cuaca & 0,643 & 0,528 \\
\hline & Pasokan Material & 0,464 & 0,470 \\
\hline & Pencurian & 0,571 & 0,488 \\
\hline & Spesifikasi & 0,286 & 0,512 \\
\hline & Mismanajemen & 0,357 & 0,519 \\
\hline & Mogok & 0,286 & 0,498 \\
\hline & Skedul (Jadwal) & 0,321 & 0,551 \\
\hline & Estimasi Biaya Konstruksi & 0,500 & 0,567 \\
\hline & Inflasi & 0,679 & 0,709 \\
\hline & Ketidakjujuran & 0,357 & 0,600 \\
\hline 3. & Peralatan & 0,518 & 0,437 \\
\hline & Impor & 0,464 & 0,463 \\
\hline & Kinerja & 0,571 & 0,437 \\
\hline 4. & Force Majeur & 0,333 & 0,504 \\
\hline & Bencana & 0,357 & 0,521 \\
\hline & Nasionalisasi & 0,357 & 0,640 \\
\hline & Dornlıci & 0 786 & 0505 \\
\hline & & & \\
\hline
\end{tabular}

Gambar 5. Perbandingan Probabilitas Kejadian Risiko.

Sumber: Hasil Pengolahan Data, 2013

\section{Pengukuran Dampak Risiko}

Adapun hasil pengukuran pengaruh atau dampak risiko pada pembangunan jalan tol Pekanbaru-Dumai dapat dilihat pada gambar 6.

Berdasarkan penelitian yang dilaksanakan ini, terdapat perbedaan yang cukup signifikan antara hasil penelitian dangan parameter dampak resiko yang dipublikasi dari Pd-T-01-2005-B sekitar 80\% untuk resiko pembiayaan proyek.

Hasil penelitian menunjukkan dampak resiko pembiayaan proyek jalan tol ini lebih besar dibanding dengan standar yang ada di PU. Hal ini berdasarkan histori sampai saat ini belum adanya akses pembiayaan proyek (dari tahun 2005 - 2014) berimplikasi pada macetnya proses persiapan dan pembangunan jalan tol ini. Sehingga dampak pembiayaan yang tidak jelas dari pembangunan jalan tol yang sudah dirasakan oleh stakeholder adalah relatif signifikan (besar). Begitu juga dampak untuk pembangunan, peralatan dan force majeur realtif lebih besar dibanding dengan hasil penelitian Pd-T-012005-B. 


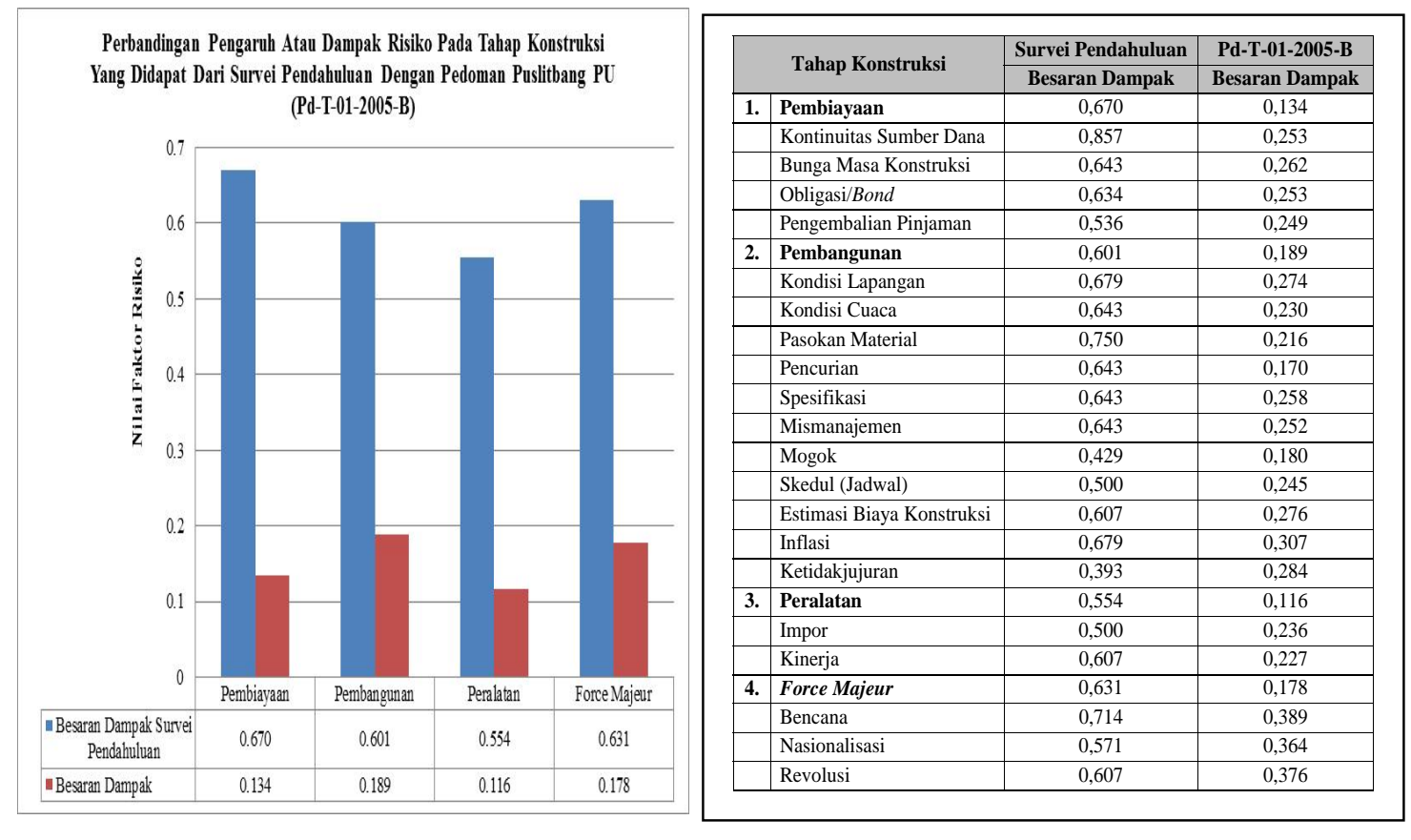

Gambar 6. Perbandingan Dampak Risiko.

Sumber: Hasil Pengolahan Data, 2013

\section{Analisis Risiko Jalan Tol}

Adapun hasil pengukuran faktor risiko dan kategorisasi risiko pada tahap konstruksi pada jalan tol Pekanbaru-Dumai dapat dilihat pada Gambar 7.

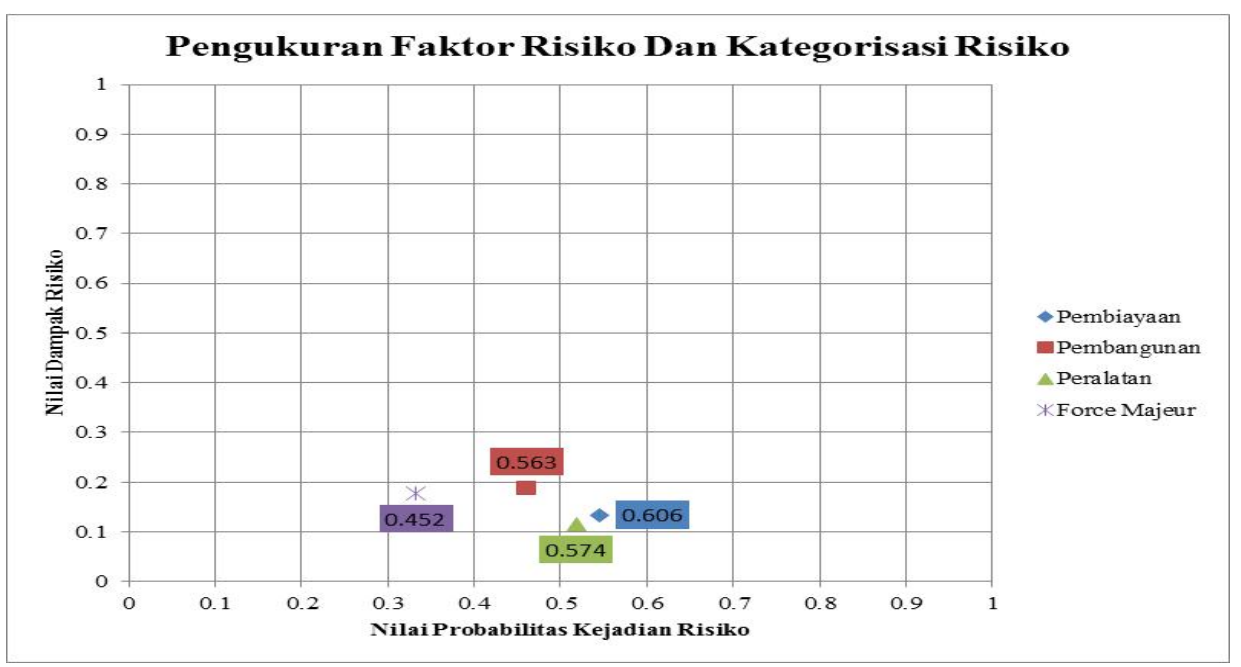

Gambar 7. Grafik Pengukuran Faktor Risiko Dan Kategorisasi Risiko.

Sumber: Hasil Pengolahan Data, 2013 
Hasil dari pengukuran faktor risiko dan kategorisasi risiko adalah sebagai berikut: risiko pembiayaan 0,606 , risiko pembangunan 0,563 , risiko peralatan 0,574 , dan force majeur 0,452. Oleh karena nilai faktor risiko lebih besar dari 0,4 dan lebih kecil dari 0,7, maka seluruh faktor risiko yang teridentifikasi pada pembangunan jalan tol PekanbaruDumai termasuk dalam kategori risiko sedang yang memerlukan perhatian untuk ditangani.

Adapun hasil pengukuran faktor risiko dan kategorisasi risiko pada tahap konstruksi pada jalan tol Pekanbaru-Dumai dapat dilihat pada Gambar 8.

Pada umumnya elemen pada faktor risiko pembiayaan berada pada klasifikasi risiko sedang, kecuali risiko kontinuitas terhadap sumber dana, kondisi lapangan (ketidak pastian lahan dan cuaca), serta fluktuasi tingkat inflasi yang berada pada klasifikasi risiko tinggi.

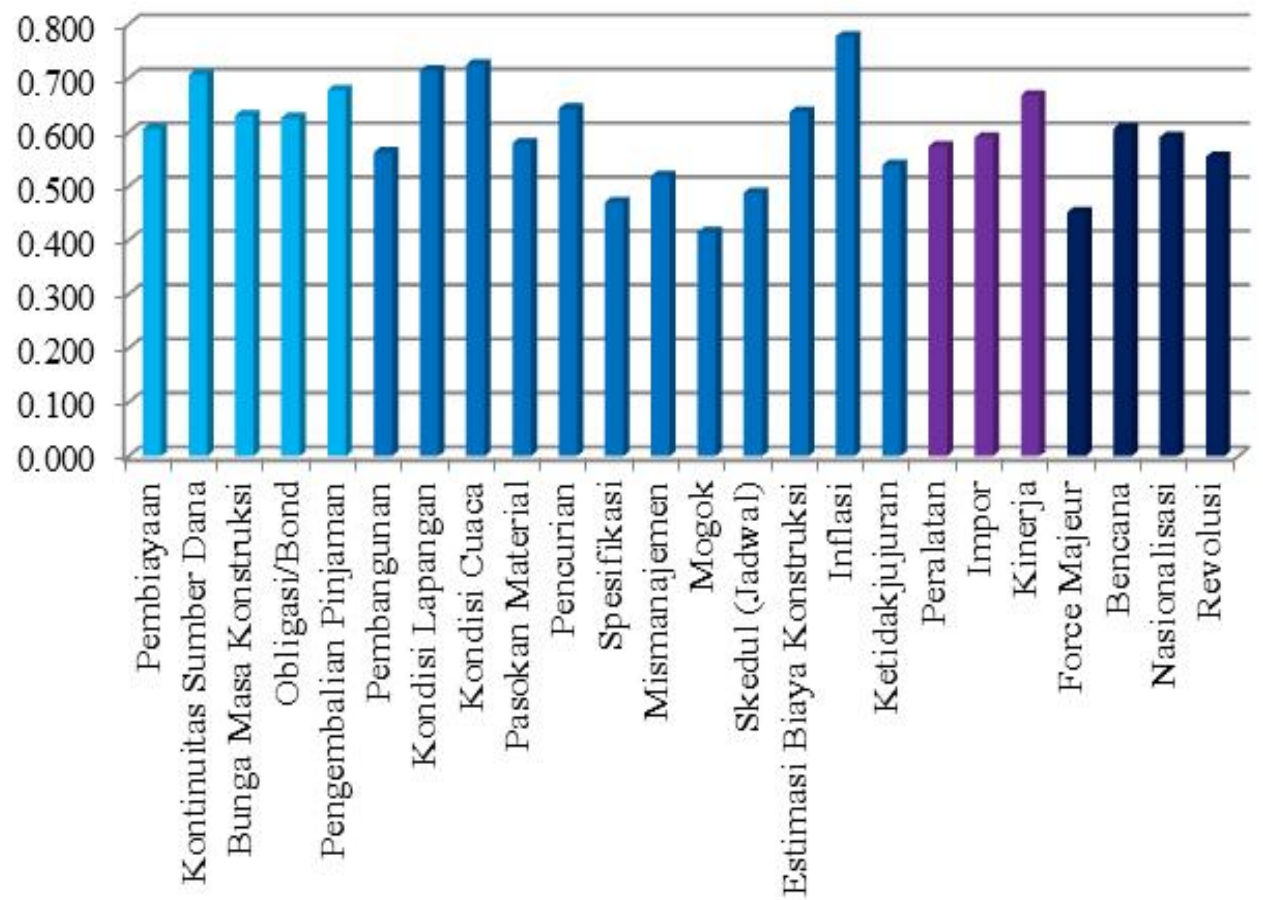

\section{Gambar 8 Grafik Faktor Risiko Dan Kategorisasi Risiko Secara Keseluruhan.}

Sumber: Hasil Pengolahan Data, 2013 


\section{Menghitung faktor risiko.}

Faktor resiko dampak merupakan perkalian antara probabilitas $\mathrm{x}$ dampak $\mathrm{x}$ besaran biaya per komponen,dengan menggunakan data probabilitas dan tingkat dampak yang telah didapat dari hasil survei.

Berdasarkan hasil analisis di atas, diperoleh elemen dari komponen risiko pembangunan memiliki faktor risiko paling tinggi $(0,778)$ jika dibandingkan dengan elemen dari komponen lainnya.

Sedangkan, besaran risiko untuk seluruh komponen jika dibandingkan dengan besaran biaya investasi yang dibutuhkan adalah sebesar 15\% atau tergolong kedalam risiko sedang berdasarkan Puslitbang PU (Pd-T-01-2005-B).

Tabel 1. Hasil Perhitungan Faktor Risiko Berdasarkan Komponen Risiko.

\begin{tabular}{|c|c|c|c|c|c|c|c|c|}
\hline \multirow{2}{*}{ No. } & \multirow{2}{*}{ Komponen Risiko } & \multirow{2}{*}{\multicolumn{2}{|c|}{ Besaran Biaya }} & \multirow{2}{*}{$\begin{array}{c}\text { Probabilitas } \\
\text { (L) }\end{array}$} & \multirow{2}{*}{$\begin{array}{c}\text { Besaran } \\
\text { Dampak (I) }\end{array}$} & \multirow{2}{*}{\multicolumn{2}{|c|}{ Besaran Risiko }} & \multirow{2}{*}{$\begin{array}{l}\text { Faktor Risiko } \\
\text { FR = L+I-( }\left(L^{*}\right) \\
\end{array}$} \\
\hline & & & & & & & & \\
\hline 1 & Pengadaan Tanah & $\mathrm{Rp}$ & $546,000,000,000.00$ & 0.527 & 0.241 & $\mathrm{Rp}$ & $69,345,822,000.00$ & 0.641 \\
\hline 2 & Perencanaan Akhir Teknik (FED) & $\mathrm{Rp}$ & $104,857,000,000.00$ & 0.305 & 0.146 & $\mathrm{Rp}$ & $4,669,282,210.00$ & 0.406 \\
\hline 3 & Mobilisasi, Demobilisasi dan Umum & $\mathrm{Rp}$ & $85,625,329,139.00$ & 0.607 & 0.274 & $\mathrm{Rp}$ & $14,241,033,491.74$ & 0.715 \\
\hline 4 & Pembersihan Tempat Kerja & $\mathrm{Rp}$ & $68,820,063,000.00$ & 0.607 & 0.274 & $\mathrm{Rp}$ & $11,446,015,238.03$ & 0.715 \\
\hline 5 & Pembongkaran & $\mathrm{Rp}$ & $15,327,153,000.00$ & 0.643 & 0.230 & $\mathrm{Rp}$ & $2,266,732,657.17$ & 0.725 \\
\hline 6 & Pekerjaan Tanah & $\mathrm{Rp}$ & $1,627,151,139,685.91$ & 0.607 & 0.274 & $\mathrm{Rp}$ & $270,624,523,250.28$ & 0.715 \\
\hline 7 & Galian Struktur & $\mathrm{Rp}$ & $5,856,410,172.00$ & 0.643 & 0.230 & $\mathrm{Rp}$ & $866,104,500.34$ & 0.725 \\
\hline 8 & Drainase & $\mathrm{Rp}$ & $279,423,759,187.98$ & 0.643 & 0.230 & $\mathrm{Rp}$ & $41,323,979,746.31$ & 0.725 \\
\hline 9 & Subgrade & $\mathrm{Rp}$ & $31,591,285,590.70$ & 0.643 & 0.230 & $\mathrm{Rp}$ & $4,672,035,226.01$ & 0.725 \\
\hline 10 & Lapis Pondasi Agregat & $\mathrm{Rp}$ & $806,646,706,920.42$ & 0.643 & 0.230 & $\mathrm{Rp}$ & $119,294,981,486.46$ & 0.725 \\
\hline 11 & Perkerasan & $\mathrm{Rp}$ & $1,888,106,203,894.80$ & 0.643 & 0.230 & $\mathrm{Rp}$ & $279,232,026,494.00$ & 0.725 \\
\hline 12 & Struktur Beton & $\mathrm{Rp}$ & $2,664,028,537,630.49$ & 0.643 & 0.230 & $\mathrm{Rp}$ & 393,983,180,430.17 & 0.725 \\
\hline 13 & Pekerjaan Baja Struktural & $\mathrm{Rp}$ & $3,607,915,050.00$ & 0.643 & 0.230 & $\mathrm{Rp}$ & $533,574,556.74$ & 0.725 \\
\hline 14 & Pekerjaan Lain-Lain & $\mathrm{Rp}$ & $417,917,230,081.79$ & 0.643 & 0.230 & $\mathrm{Rp}$ & $61,805,779,156.80$ & 0.725 \\
\hline 15 & Pencahayaan Lampu Lalu Lintas \& Pekerjaan Listrik & $\mathrm{Rp}$ & $41,566,236,573.00$ & 0.643 & 0.230 & $\mathrm{Rp}$ & $6,147,230,726.78$ & 0.725 \\
\hline 16 & Pekerjaan Plaza Tol & $\mathrm{Rp}$ & $35,710,585,428.50$ & 0.643 & 0.230 & $\mathrm{Rp}$ & $5,281,238,479.02$ & 0.725 \\
\hline 17 & Pengalihan dan Perlindungan Utilitas Yang Ada & $\mathrm{Rp}$ & $76,220,737,668.71$ & 0.643 & 0.230 & $\mathrm{Rp}$ & $11,272,284,893.83$ & 0.725 \\
\hline 18 & Pekerjaan Fasilitas Tol & $\mathrm{Rp}$ & $18,300,380,000.00$ & 0.643 & 0.230 & $\mathrm{Rp}$ & $2,706,443,198.20$ & 0.725 \\
\hline 19 & Peralatan \& Perlengkapan Operasi & $\mathrm{Rp}$ & $120,988,000,000.00$ & 0.518 & 0.116 & $\mathrm{Rp}$ & $7,269,926,944.00$ & 0.574 \\
\hline 20 & Supervisi & $\mathrm{Rp}$ & $137,120,000,000.00$ & 0.321 & 0.245 & $\mathrm{Rp}$ & $10,783,802,400.00$ & 0.487 \\
\hline 21 & Eskalasi & $\mathrm{Rp}$ & 2,314,496,000,000.00 & 0.679 & 0.307 & $\mathrm{Rp}$ & $482,463,634,688.00$ & 0.778 \\
\hline 22 & Kontingensi & $\mathrm{Rp}$ & 409,344,000,000.00 & 0.607 & 0.253 & $\mathrm{Rp}$ & $62,863,367,424.00$ & 0.706 \\
\hline 23 & PPN & $\mathrm{Rp}$ & $1,115,271,000,000.00$ & 0.545 & 0.134 & $\mathrm{Rp}$ & $81,448,241,130.00$ & 0.606 \\
\hline 24 & Overhead Proyek & $\mathrm{Rp}$ & $209,085,000,000.00$ & 0.607 & 0.253 & $\mathrm{Rp}$ & $32,109,392,535.00$ & 0.706 \\
\hline 25 & Financial Cost & $\mathrm{Rp}$ & $112,485,000,000.00$ & 0.607 & 0.253 & $\mathrm{Rp}$ & $17,274,433,935.00$ & 0.706 \\
\hline \multirow[t]{3}{*}{26} & Bunga Selama Masa Konstruksi & $\mathrm{Rp}$ & $1,521,863,000,000.00$ & 0.500 & 0.262 & $\mathrm{Rp}$ & $199,364,053,000.00$ & 0.631 \\
\hline & & $\mathrm{Rp}$ & $14,657,408,673,023.30$ & & & $\mathrm{Rp}$ & 2,193,289,119,797.89 & 0.685 \\
\hline & & & & & & & $15 \%$ & Risiko Sedang \\
\hline
\end{tabular}

Sumber: Financial Analysis Jalan Tol Pekanbaru-Dumai, Dinas PU Provinsi Riau, Bidang Bina Marga, Seksi Perencanaan Teknis, 2011.

\section{Simulasi Risiko Investasi Tahap Konstruksi Dengan Menggunakan @RiskFor Excel}

Untuk menguji sensitifitas risiko tahap konstruksi ini dibagi menjadi 4 (empat) alternatif. 


\section{a. Alternatif I}

Alternatif pertama ini dikembangkan dengan data probabilitas risiko yang diambil melalui survei pendahuluan dan data besaran dampak risiko yang diambil dari Puslitbang Jembatan dan Jalan Pd-T-01-2005-B.

Tabel 2. Hasil Perhitungan Lengkap Dari Risiko Investasi Pembangunan Jalan Tol Pekanbaru-Dumai Tahap Konstruksi Alternatif I.

\begin{tabular}{|c|c|c|c|c|c|c|c|c|c|}
\hline \multirow{2}{*}{ No. } & \multirow{2}{*}{ Komponen Risiko } & \multirow{2}{*}{\multicolumn{2}{|c|}{ Besaran Biaya }} & \multicolumn{6}{|c|}{ Deviasi } \\
\hline & & & & \multicolumn{2}{|r|}{ Minimum } & \multicolumn{2}{|r|}{ Most Likely } & \multicolumn{2}{|r|}{ Maksimum } \\
\hline 1 & Pengadaan Tanah & $\mathrm{Rp}$ & $546,000,000,000.00$ & Rp & $491,400,000,000.00$ & Rp & $546,000,000,000.00$ & $\mathrm{Rp}$ & $615,345,822,000.00$ \\
\hline 2 & Perencanaan Akhir Teknik (FED) & $\mathrm{Rp}$ & $104,857,000,000.00$ & $\mathrm{Rp}$ & $94,371,300,000.00$ & $\mathrm{Rp}$ & $104,857,000,000.00$ & $\mathrm{Rp}$ & $109,526,282,210.00$ \\
\hline 3 & Mobilisasi, Demobilisasi dan Umum & $\mathrm{Rp}$ & $85,625,329,139.00$ & $\mathrm{Rp}$ & $81,344,062,682.05$ & $\mathrm{Rp}$ & $85,625,329,139.00$ & $\mathrm{Rp}$ & $99,866,362,630.74$ \\
\hline 4 & Pembersihan Tempat Kerja & $\mathrm{Rp}$ & $68,820,063,000.00$ & $\mathrm{Rp}$ & $65,379,059,850.00$ & Rp & $68,820,063,000.00$ & $\mathrm{Rp}$ & $80,266,078,238.03$ \\
\hline 5 & Pembongkaran & $\mathrm{Rp}$ & $15,327,153,000.00$ & $\mathrm{Rp}$ & $14,560,795,350.00$ & $\mathrm{Rp}$ & $15,327,153,000.00$ & $\mathrm{Rp}$ & $17,593,885,657.17$ \\
\hline 6 & Pekerjaan Tanah & $\mathrm{Rp}$ & $1,627,151,139,685.91$ & $\mathrm{Rp}$ & $1,464,436,025,717.32$ & $\mathrm{Rp}$ & $1,627,151,139,685.91$ & $\mathrm{Rp}$ & $1,897,775,662,936.19$ \\
\hline 7 & Galian Struktur & $\mathrm{Rp}$ & $5,856,410,172.00$ & $\mathrm{Rp}$ & $5,270,769,154.80$ & $\mathrm{Rp}$ & $5,856,410,172.00$ & $\mathrm{Rp}$ & $6,722,514,672.34$ \\
\hline 8 & Drainase & $\mathrm{Rp}$ & $279,423,759,187.98$ & Rp & $265,452,571,228.58$ & $\mathrm{Rp}$ & $279,423,759,187.98$ & $\mathrm{Rp}$ & $320,747,738,934.29$ \\
\hline 9 & Subgrade & $\mathrm{Rp}$ & $31,591,285,590.70$ & $\mathrm{Rp}$ & $30,011,721,311.17$ & $\mathrm{Rp}$ & $31,591,285,590.70$ & $\mathrm{Rp}$ & $36,263,320,816.71$ \\
\hline 10 & Lapis Pondasi Agregat & $\mathrm{Rp}$ & $806,646,706,920.42$ & $\mathrm{Rp}$ & $766,314,371,574.40$ & $\mathrm{Rp}$ & $806,646,706,920.42$ & $\mathrm{Rp}$ & $925,941,688,406.88$ \\
\hline 11 & Perkerasan & $\mathrm{Rp}$ & 1,888,106,203,894.80 & $\mathrm{Rp}$ & $1,699,295,583,505.32$ & Rp & $1,888,106,203,894.80$ & $\mathrm{Rp}$ & 2,167,338,230,388.80 \\
\hline 12 & Struktur Beton & $\mathrm{Rp}$ & $2,664,028,537,630.49$ & $\mathrm{Rp}$ & $2,397,625,683,867.44$ & $\mathrm{Rp}$ & $2,664,028,537,630.49$ & $\mathrm{Rp}$ & $3,058,011,718,060.66$ \\
\hline 13 & Pekerjaan Baja Struktural & $\mathrm{Rp}$ & $3,607,915,050.00$ & $\mathrm{Rp}$ & $3,247,123,545.00$ & $\mathrm{Rp}$ & $3,607,915,050.00$ & Rp & $4,141,489,606.74$ \\
\hline 14 & Pekerjaan Lain-Lain & $\mathrm{Rp}$ & $417,917,230,081.79$ & $\mathrm{Rp}$ & $397,021,368,577.70$ & Rp & $417,917,230,081.79$ & $\mathrm{Rp}$ & $479,723,009,238.59$ \\
\hline 15 & Pencahayaan Lampu Lalu Lintas \& Pekerjaan Listrik & $\mathrm{Rp}$ & $41,566,236,573.00$ & Rp & $37,409,612,915.70$ & $\mathrm{Rp}$ & $41,566,236,573.00$ & Rp & $47,713,467,299.78$ \\
\hline 16 & Pekerjaan Plaza Tol & Rp & $35,710,585,428.50$ & Rp & $32,139,526,885.65$ & Rp & $35,710,585,428.50$ & Rp & $40,991,823,907.52$ \\
\hline 17 & Pengalihan dan Perlindungan Utilitas Yang Ada & $\mathrm{Rp}$ & $76,220,737,668.71$ & $\mathrm{Rp}$ & $68,598,663,901.84$ & $\mathrm{Rp}$ & $76,220,737,668.71$ & $\mathrm{Rp}$ & $87,493,022,562.54$ \\
\hline 18 & Pekerjaan Fasilitas Tol & $\mathrm{Rp}$ & $18,300,380,000.00$ & $\mathrm{Rp}$ & $16,470,342,000.00$ & $\mathrm{Rp}$ & $18,300,380,000.00$ & $\mathrm{Rp}$ & $21,006,823,198.20$ \\
\hline 19 & Peralatan \& Perlengkapan Operasi & $\mathrm{Rp}$ & $120,988,000,000.00$ & $\mathrm{Rp}$ & $114,938,600,000.00$ & $\mathrm{Rp}$ & $120,988,000,000.00$ & $\mathrm{Rp}$ & $128,257,926,944,00$ \\
\hline 20 & Supervisi & $\mathrm{Rp}$ & $137,120,000,000.00$ & $\mathrm{Rp}$ & $130,264,000,000.00$ & $\mathrm{Rp}$ & $137,120,000,000.00$ & $\mathrm{Rp}$ & $147,903,802,400.00$ \\
\hline 21 & Eskalasi & $\mathrm{Rp}$ & $2,314,496,000,000.00$ & $\mathrm{Rp}$ & $2,198,771,200,000.00$ & $\mathrm{Rp}$ & $2,314,496,000,000.00$ & $\mathrm{Rp}$ & $2,796,959,634,688.00$ \\
\hline 22 & Kontingensi & $\mathrm{Rp}$ & $409,344,000,000.00$ & Rp & $388,876,800,000.00$ & $\mathrm{Rp}$ & $409,344,000,000.00$ & $\mathrm{Rp}$ & $472,207,367,424.00$ \\
\hline 23 & PPN & $\mathrm{Rp}$ & $1,115,271,000,000.00$ & $\mathrm{Rp}$ & $1,059,507,450,000.00$ & $\mathrm{Rp}$ & $1,115,271,000,000.00$ & $\mathrm{Rp}$ & $1,196,719,241,130.00$ \\
\hline 24 & Overhead Proyek & $\mathrm{Rp}$ & $209,085,000,000.00$ & $\mathrm{Rp}$ & $198,630,750,000.00$ & $\mathrm{Rp}$ & $209,085,000,000.00$ & $\mathrm{Rp}$ & $241,194,392,535.00$ \\
\hline 25 & Financial Cost & $\mathrm{Rp}$ & $112,485,000,000.00$ & $\mathrm{Rp}$ & $106,860,750,000.00$ & $\mathrm{Rp}$ & $112,485,000,000.00$ & Rp & $129,759,433,935.00$ \\
\hline \multirow[t]{2}{*}{26} & Bunga Selama Masa Konstruksi & $\mathrm{Rp}$ & $1,521,863,000,000.00$ & $\mathrm{Rp}$ & $1,445,769,850,000.00$ & Rp & $1,521,863,000,000.00$ & $\mathrm{Rp}$ & $1,721,227,053,000.00$ \\
\hline & & $\mathrm{Rp}$ & 14,657,408,673,023.30 & $\mathrm{Rp}$ & 13,573,967,982,067.00 & $\mathrm{Rp}$ & $14,657,408,673,023.30$ & $\mathrm{Rp}$ & $16,850,697,792,821.20$ \\
\hline
\end{tabular}

Sumber: Hasil Pengolahan Data, 2013

Dari hasil simulasi dengan menggunakan distribusi triangle (menggunakan model 2 tails 90\% value dengan 5\% error), diperoleh nilai rata-rata (mean value atau 5050 chance) adalah Rp. 15,03 trilyun dengan range rencana anggran biaya Rp. 14,33 trilyun sampai Rp. 15,77 trilyun.

Sedangkan untuk mengetahui seberapa sensitif elemen-elemen risiko digambarkan dalam diagram tornado regresi sensitivitas dan diagram tornado korelasi sensitivitas gambar 9. Berdasarkan gambar diatas terlihat risiko pembangunan jalan tol Pekanbaru-Dumai pada tahap konstruksi yang paling sensitif adalah pembangunan struktur beton $(0,55)$, konstruksi perkerasan $(0,53)$, pembayaran bunga bank dan pembayaran pajak (PPN).

Analisis Risiko Pembangunan Jalan Tol Pada Tahap Konstruksi

(Studi Kasus Jalan Tol Pekanbaru - Dumai) (Ari Sandhyavitri, Muhammad Zulfiqar) 

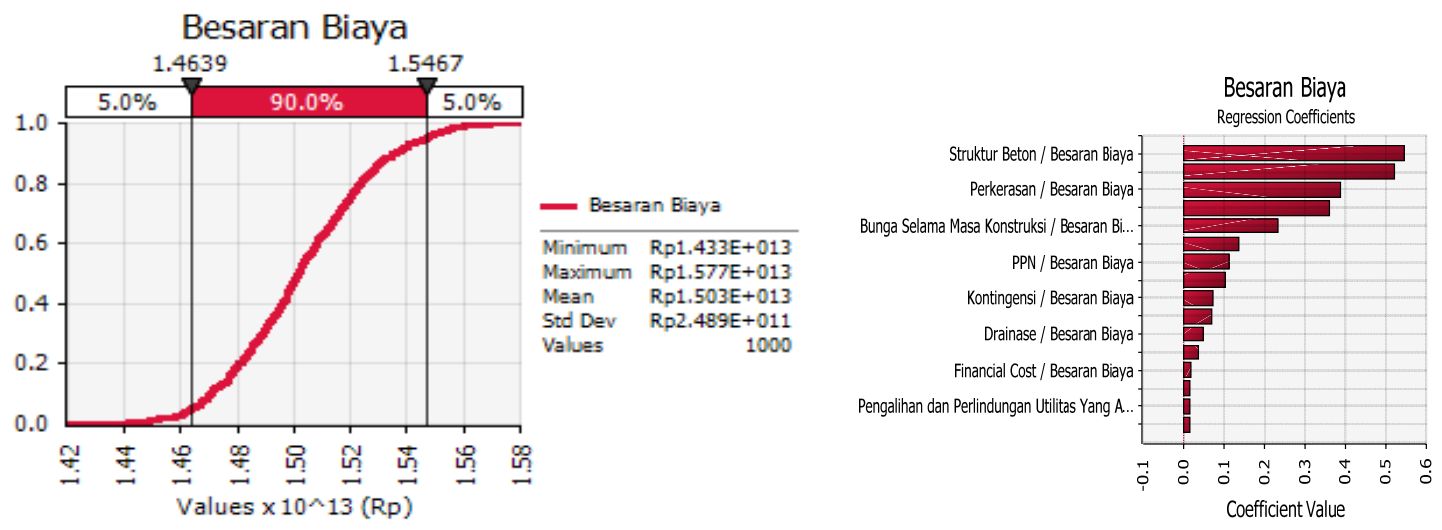

Gambar 9. Hasil Simulasi Risiko Investasi Alternatif I dan diagram tornado regresi sensitivitas. Sumber: Hasil Pengolahan data, 2013

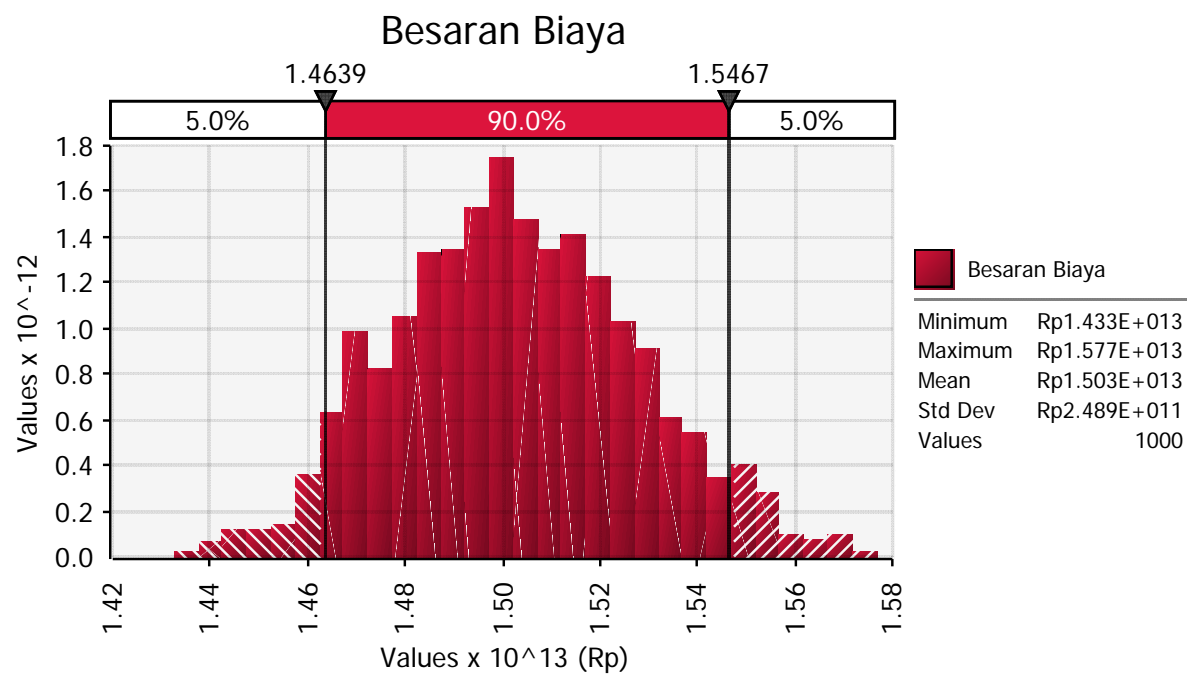

\section{Gambar 10. Hasil Simulasi Distribusi Risiko Investasi Alternatif I.}

Sumber: Hasil Pengolahan data, 2013

\section{b. Alternatif II}

Alternatif kedua ini dikembangkan dengan data probabilitas risiko dan data besaran dampak risiko yang diambil melalui survei pendahuluan, diperoleh nilai rata-rata (mean value)adalah Rp. 16,23 trilyun dengan range rencana anggran biaya Rp. 14,66 trilyun sampai Rp. 17,96 trilyun. 


\section{c. Alternatif III}

Alternatif ketiga ini dikembangkan dengan data probabilitas risiko yang diambil melalui survei pendahuluan dan data besaran dampak risiko yang diambil melalui survei detail kepada Kepala Seksi Perencanaan Bidang Bina Marga Dina PU Provinsi Riau, diperoleh nilai rata-rata (mean value) adalah Rp. 14,96 trilyun dengan range rencana anggran biaya Rp. 14,19 trilyun sampai Rp. 15,75 trilyun.

\section{d. Alternatif IV}

Alternatif keempat ini dikembangkan dengan data probabilitas risiko yang diambil melalui survei pendahuluan dan data besaran dampak risiko yang diambil melalui survei detail kepada Kepala Seksi Perencanaan Bidang Bina Marga Dina PU Provinsi Riau dengan anggapan bahwa Pemerintah dapat mengontrol risiko dengan melakukan pengelolaan risiko, diperoleh nilai rata-rata (mean value) adalah Rp. 14,63 trilyun dengan range rencana anggran biaya Rp. 14,15 trilyun sampai Rp. 15,08 trilyun. Adapun pengelolaan risiko yang akan dilaksanakan antara lain adalah;

Tabel 3. Ringkasan 4 (empat) Alternatif yang dikembangkan.

\begin{tabular}{|c|c|c|c|c|}
\hline \multirow{2}{*}{ Alternatif } & \multicolumn{3}{|c|}{ Estimasi Nilai Investasi (Rp) trilyun } & \multirow{2}{*}{ Keterangan } \\
\cline { 2 - 4 } & Minimal & Rata-Rata & Maksimal & \\
\hline Alternatif I & 14,33 & 15,03 & 15,77 & \\
\hline Alternatif II & 14,66 & 16,23 & 17,96 & \\
\hline Alternatif IIII & 14,19 & 14,96 & 15,75 & \\
\hline Alternatif IV & 14,15 & 14,63 & 15,08 & \\
\hline
\end{tabular}

Berdasarkan tabel di atas maka dapat diringkas sebagai berikut:

Alternatif I yang merupakan pengembangan data dari Puslitbang Jembatan dan Jalan Pd-T-01-2005-B, diperoleh nilai rata-rata (mean value) pembiayaan sebesar Rp. 15,028 trilyun, dengan 95\% peluang proyek dapat dilaksanakan dengan biaya Rp. 15,77 triliyun.

Alternatif II yang merupakan pengembangan data dari survei pendahuluan, diperoleh nilai rata-rata (mean value atau 50-50 chance) pembiayaan sebesar Rp. 16,233 trilyun, dengan 95\% peluang proyek dapat dilaksanakan dengan biaya Rp. 17,96 triliyun. 
Alternatif III yang merupakan pengembangan data dari survei detail (sebelum mitigasi risiko), diperoleh nilai rata-rata (mean value) pembiayaan sebesar Rp. 14,96 trilyun, dengan 95\% peluang proyek dapat dilaksanakan dengan biaya Rp. 15,75 triliyun.

Alternatif IV yang merupakan pengembangan data dari survei detail (setelah mitigasi risiko), diperoleh nilai rata-rata (mean value) Rp. 14,63 trilyun, dengan 95\% peluang proyek dapat dilaksanakan dengan biaya Rp. 15,08 triliyun.

Dari 4 (empat) alternatif tergambarkan nilai rata-rata proyek (mean value atau 5050 chance) akan lebih kecil dari nilai dengan peluang sukses 95\%. Mitigasi risiko dapat berpeluang memperkecil jarak estimasi nilai proyek setelah mitigasi dibandingkan dengan nilai sebelum mitigasi (misalnya nilai rata-rata untuk pelaksanaan proyek sebelum mitigasi adalah 14,96 dan setelah mitigasi 14,63 triliyun (ada selisih Rp. 33 miliar). Sehingga analisis risiko dan mitigasi risiko perlu untuk dilaksanakan dalam proyek konstruksi jalan tol karena dapat mengefisienkan dana dalam jumlah yang relatif signifikan.

\section{KESIMPULAN}

Ada 4 (empat) risiko utama yang diidentifikasi yaitu: risiko pembiayaan, risiko pembangunan, risiko peralatan dan risiko force majeur. Terdapat perbedaan besarnya probabilitas risiko dan dampak risiko yang diukur pada proyek pembangunan jalan tol Pekanbaru-Dumai tahap konstruksi dibandingkan tipikal probabilitas kejadian risiko investasi jalan tol di Indonesia yang bersumber dari Puslitbang PU. Hal ini disebabkan oleh adanya perbedaan karakteristik daerah Provinsi Riau baik di Pekanbaru, Kandis, Duri, maupun Kota Dumai. Analisis risiko dan mitigasi risiko perlu untuk dilaksanakan dalam proyek konstruksi jalan tol karena dapat mengefisienkan dana dalam jumlah yang relatif signifikan.

\section{DAFTAR PUSTAKA}

1. Anonim. 2012. Jalan Tol. Tersedia di: <http://id.wikipedia.org/wiki/jalan_tol> [Diakses tanggal 25 Agustus 2012].

2. Anonim. 2011. Masterplan Percepatan dan Perluasan Pembangunan Ekonomi Indonesia (MP3EI). Jakarta.

3. Ali, T.H. 1997. Prinsip-Prinsip Network Planning. Jakarta: PT. Gramedia Pustaka Utama.

4. $\quad$ Dipohusodo, I. 1996. Manajemen Proyek \& Konstruksi Jilid I \& II. Yogyakarta: Kanisius. 
5. Gubernur Riau, 2009. Persentasi Pembangunan Jalan Tol Pekanbaru-Dumai di Provinsi Riau. Pekanbaru: Dinas Pemukiman dan Prasarana Wilayah Provinsi Riau.

6. Halpin, D. W., Woodhead, R. W., 1998. Construction Management. John Wiley \& Sons, Canada.

7. Levin, R.I., Kirkpatrick, C.A. 1987. Perencanaan dan Pengendalian dengan PERT dan CPM. Balai Pustaka.

8. Ningrum Ratna, 2008. Analisis Risiko Investasi Jalan Tol Depok Antasari. Institut Teknologi Bandung. Bandung.

9. Pusat Litbang Prasarana Transportasi, 2003.Pengembangan Metode Analisis Risiko Investasi Jalan Tol. Jakarta: Departemen Pekerjaan Umum.

10. Raftery, J., 1986. Risk Analysis in Project Management. London: E \& F Spon.

11. Ronald, M., 2003. Manajemen Pembangunan, Jakarta: Grafikatama Abdiwacana.

12. Sandhyavitri, A., Saputra, N., 2013. Analisis Risiko Jalan Tol Tahap Pra Konstruksi (Studi Kasus Jalan Tol Pekanbaru-Dumai), Jurnal Teknik Sipil Volume 9 Nomor 1, April 2013 : 1-83, UNS.

13. Smith, N. J., (Editor), 1995. Engineering Project Management. Blackweell Science, London.

14. Soeharto, I. 1995. Manajemen Proyek Dari Konseptual Sampai Operasional. Erlangga.

15. Zulfery, 2004. Analisis Investasi Pembangunan Jalan Tol Pekanbaru-Dumai. Intitut Teknologi Bandung. Bandung. 